\title{
CHANGES OF INTRACELLULAR SODIUM AND POTASSIUM ION CONCENTRATIONS IN FROG SPINAL MOTONEURONS INDUCED BY REPETITIVE SYNAPTIC STIMULATION
}

\author{
P. Grafe, J. Rimpel, M. M. Reddy and G. Ten Bruggencate \\ Department of Physiology, University of München, Pettenkoferstr. 12, D-8000 München 2, F.R.G.
}

\begin{abstract}
A post-tetanic membrane hyperpolarization following repetitive neuronal activity is a commonly observed phenomenon in the isolated frog spinal cord as well as in neurons of other nervous tissues. We have now used double-barrelled $\mathrm{Na}^{+}$- and $\mathrm{K}^{+}$-ion-sensitive microelectrodes to measure the intracellular $\mathrm{Na}^{+}$- and $\mathrm{K}^{+}$-concentrations and also the extracellular $\mathrm{K}^{+}$-concentration of lumbar spinal motoneurons during and after repetitive stimulation of a dorsal root. The results show that the posttetanic membrane hyperpolarization occurred at a time when the intracellular $\left[\mathrm{Na}^{+}\right]$reached its maximal value, intracellular $\left[\mathrm{K}^{+}\right]$had its lowest level and extracellular $\left[\mathrm{K}^{+}\right]$was still elevated. The hyperpolarization was blocked by ouabain and reduced by $\mathrm{Li}^{+}$.

These data support the previous suggestion that an electrogenic $\mathrm{Na}^{+} / \mathrm{K}^{+}$pump mode may be the mechanism underlying the post-tetanic membrane hyperpolarization.
\end{abstract}

Repetitive neuronal activity in many preparations is often followed by a post-tetanic membrane hyperpolarization (PTH). ${ }^{2,13,17,21,28}$ Such a hyperpolarization has also been observed at primary afferents of the isolated frog spinal cord following tetanic stimulation of an adjacent dorsal root. ${ }^{6,7,19}$ Measurements with ion-sensitive microelectrodes in that preparation revealed that the free extracellular potassium concentration $\left[\mathrm{K}^{+}\right]_{\mathrm{e}}$ was still elevated during the period of the PTH. ${ }^{6.19}$ Since the reduced transmembrane $\mathrm{K}^{+}$-gradient would rather depolarize the membrane, the activation of an electrogenic $\mathrm{Na}^{+}$pump was suggested to be the most likely explanation for the PTH. ${ }^{6,7,19}$ However, no information was available about the intracellular free sodium $\left[\mathrm{Na}^{+}\right]_{i}$ and potassium concentrations $\left[\mathrm{K}^{+}\right]_{\mathrm{i}}$ in the neuronal elements involved in the PTH.

Recently, it has been shown that motoneurons of the isolated frog spinal cord allow stable intracellular recordings with double barrelled ion-sensitive microelectrodes. ${ }^{3,23}$ Therefore, we have now used $\mathrm{Na}^{+}$and $\mathrm{K}^{+}$-ion-sensitive microelectrodes together with conventional electrodes to determine the changes of $\left[\mathrm{Na}^{+}\right]_{b}\left[\mathrm{~K}^{+}\right]_{i}$ and the input resistance of spinal motoneurons induced by repetitive stimulation of a dorsal root.

\section{EXPERIMENTAL PROCEDURES}

Preparation. Experiments were performed on the isolated frog spinal cord (Rana esculenta) with the techniques de-

Abbreviations: PTH, post-tetanic membrane hyperpolarization; $\left[\mathrm{Na}^{+}\right]_{e, i}$, extracellular and intracellular concentrations, respectively of free sodium ions; $\left[\mathrm{K}^{+}\right]_{e, i}$, extracellular and intracellular concentrations, respectively, of free potassium ions. scribed in detail by Sonnhof et al. ${ }^{25}$ After decapitation, ventral laminectomy was performed in cooled Ringer's solution. The spinal cord, including dorsal and ventral roots of the lumbar segments, was removed and placed in a recording chamber (volume $1.5 \mathrm{ml}$ ), which was continuously superfused with Ringer's solution by means of a roller pump $(2.5 \mathrm{ml} / \mathrm{min})$. The Ringer's solution contained (mmol/1): $\mathrm{NaCl} 98.0, \mathrm{KCl} 3.6, \mathrm{CaCl}_{2} 2.0, \mathrm{NaHCO}_{3}$ 12.0, glucose 10.0. The $\mathrm{pH}$ was continuously monitored and adjusted to 7.3-7.5 by varying the proportion of $\mathrm{O}_{2}$ and $\mathrm{CO}_{2}$ in the gassing mixture. The temperature of the perfusion fluid was kept at $18-21^{\circ} \mathrm{C}$. The dorsal roots of the lumbar segments of one side were placed on silver wire electrodes for stimulation and covered with vaseline and the ventral roots of the same side were drawn into glass suction electrodes for stimulation or recording from the ventral roots. Motoneurons were impaled by means of a step motor driven manipulator. ${ }^{24}$

Ion-sensitive microelectrodes. The method used for the construction of the double barrelled ion-sensitive microelectrodes with tip diameters between 0.5 and $1 \mu \mathrm{m}$ was described elsewhere ${ }^{8}$ For the determination of the extraand intracellular free $\mathrm{K}^{*}$ concentrations, a Corning ion exchanger resin (477317) was filled into the ion sensitive barrel; the reference barrel contained $1 \mathrm{~mol} / \mathrm{l}$ magnesium acetate (resistances of ion exchanger barrel, 2-8 G $\Omega$; and reference barrel, 15-30 M $\Omega$ ). All electrodes were calibrated before and after the experiment in solutions containing 3 , 12 and $60 \mathrm{mmol} / 1 \mathrm{KCl}$ with a constant background of $150 \mathrm{mmol} / \mathrm{l} \mathrm{NaCl}$. A computer programme was used to calculate the slope and the selectivity coefficients of the electrodes. Only electrodes with a slope of $52-59 \mathrm{mV} / \mathrm{ten}$ fold change of $\mathrm{K}^{+}$concentration were used in the experiment and their mean selectivity ratio was: $\mathrm{K}: \mathrm{Na}=1: 0.01-0.02$. To determine $\left[\mathrm{K}^{+}\right]$, the voltage jump of the pure ion signal (voltage change of ion sensitive barrel minus voltage change of reference barrel) obtained by withdrawing the electrode from the motoneuron into the extracellular space was analysed by a computer pro- 
gramme using the selectivity ratio and the slope of the $\mathrm{K}^{+}$-ion-sensitive microelectrode and taking into account the ratio of the known extracellular to an estimated intracellular $\mathrm{Na}^{+}$background $(10 \mathrm{mmol} / \mathrm{l})$

The intracellular free $\mathrm{Na}^{+}$concentrations $\left[\mathrm{Na}^{+}\right]_{i}$ was determined using two kinds of ion exchanger resins. The reference barrel always contained $4 \mathrm{~mol} / / \mathrm{K}^{+}$acetate. In some ion-sensitive microelectrodes, the ion-sensitive barrel was filled with the $\mathrm{Li}^{+}$ion exchanger ${ }^{9}$ having mean selectivity ratios for Li:Ca:Na:K=1:0.18:0.05:0.01. The disadvantage of this ion exchanger with respect to the determination of $\left[\mathrm{Na}^{+}\right]$, was its low discrimination against $\mathrm{K}^{+}$; in addition, the high resistance $(20-100 \mathrm{G} \Omega)$ induced a slow electrical response time. However, in a few cases we were successful in reducing the resistance considerably by using electrodes with a tip size of about $1.5 \mu \mathrm{m}$ (see Fig. 3). This procedure, on the other hand, limited the probability of obtaining long lasting impalements. Therefore, most of the experiments were performed using a $\mathrm{Na}^{+}$-ion exchanger resin (ETH 227) containing a small amount of tetrachlorophenylborate ${ }^{20.26}$ (mean selectivity ratios: $\mathrm{Ca}: \mathrm{Na}: \mathrm{K}=2-4: 1: 0.025$ ). Electrodes filled with this ion exchanger had lower resistances $(10 \mathrm{G} \Omega)$ and a good discrimination between $\mathrm{Na}^{+}$and $\mathrm{K}^{+}$, although its high $\mathrm{Ca}^{2+}$ sensitivity has to be taken into account (see Discussion). The selectivity coefficients of both types of ion exchangers were determined by using solutions containing different concentrations of $\mathrm{Na}^{+}$with a constant background of $\mathrm{Ca}^{2+}$ or $\mathrm{K}^{+}$. The data were then analysed by a computer programme based on the Nicolsky equation. $\left[\mathrm{Na}^{+}\right]_{i}$ was determined by comparing the voltage of the pure ion signal obtained by withdrawing the electrode from the motoneuron into the extracellular space with the voltage obtained by changing the normal Ringer's solution to solutions containing no $\mathrm{Ca}^{2+}$ and a constant ionic strength, i.e. $\mathrm{Na}^{+}$plus $\mathrm{K}^{+}$concentration was constant $(120 \mathrm{mmol} / 1)$ and mixed in an alternating way (in $\mathrm{mmol} / 1$ ): $120 \mathrm{KCl}+0 \mathrm{NaCl} ; \quad 115 \mathrm{KCl}+5 \mathrm{NaCl} ; \quad 110 \mathrm{KCl}+$ $10 \mathrm{NaCl}$ etc.

All values of intracellular $\mathrm{Na}^{+}$and $\mathrm{K}^{+}$are given in free ion concentrations. A conversion into ion activities was not performed.

\section{RESULTS}

\section{General observations}

After impaling a motoneuron with a double-barrelled ion-sensitive microelectrode (tip size $0.5-1 \mu \mathrm{m}$ ) usually a time of $20 \mathrm{~min}$ or more elapsed until the free intracellular $\mathrm{K}^{+}-\left[\mathrm{K}^{+}\right]_{i}$ and $\mathrm{Na}^{+}$-concentrations $\left[\mathrm{Na}^{+}\right]_{i}$ reached a stable level. During this time, in spite of a hyperpolarizing trend of the membrane potential, $\left[\mathrm{K}^{+}\right]$, and $\left[\mathrm{Na}^{+}\right]$, first shifted to lower and higher concentrations, respectively. After some minutes, however, a longer lasting 'sealing' period started, characterized by an increase of $\left[\mathrm{K}^{+}\right]$, and a decrease

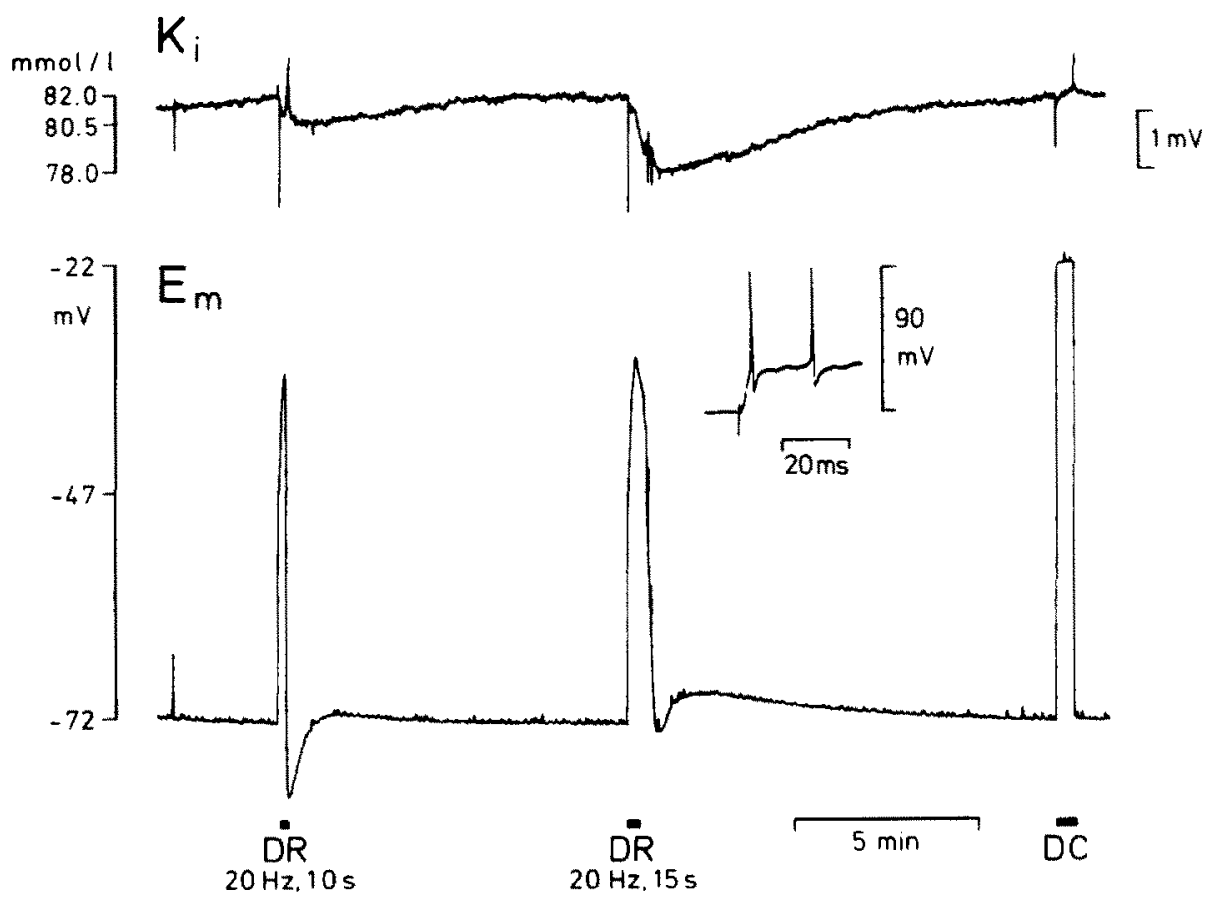

Fig. 1. Change of intracellular $\mathrm{K}^{+}$concentration $\left(\mathrm{K}_{i}\right)$ of a frog spinal motoneuron during repetitive stimulation of a lumbar dorsal root (two stimulation periods with different durations). The upper trace is the recording of the pure ion signal $\left(\mathrm{K}_{\mathrm{i}}\right)$, the lower trace is that of the reference barrel $\left(\mathrm{E}_{\mathrm{m}}\right)$ of a $\mathrm{K}^{+}$-ion-sensitive microelectrode. The bar at the end of the trace (DC) indicates a period in which a $50 \mathrm{mV}$ voltage pulse was applied between the bath and the main ground. This procedure was performed in order to test the gain adjustment of the amplifier. Note that a post-tetanic membrane hyperpolarization appeared after the end of the repetitive stimulation of a lumbar dorsal root (DR). $\mathrm{K}_{\mathrm{i}}$ had its lowest value at this time. The inset shows the post-tetanic potential with superimposed spikes induced by the first shock of the stimulus train. 


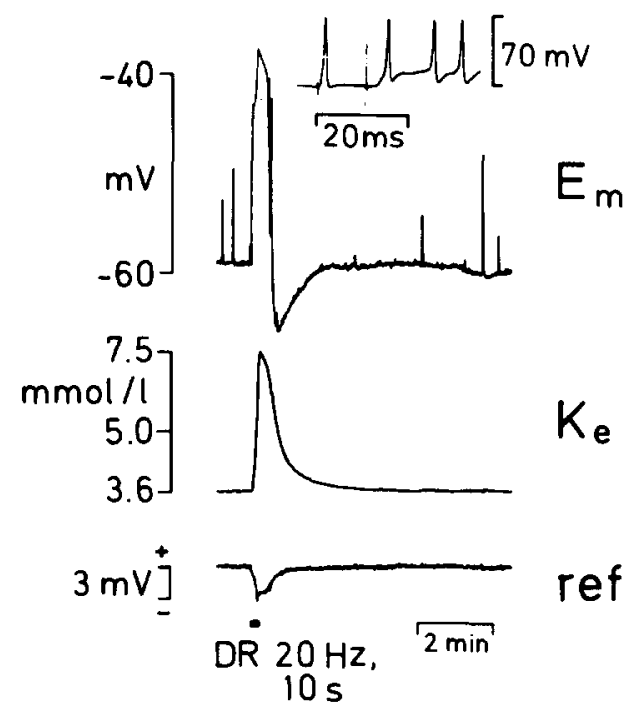

Fig. 2. Extracellular $K^{+}$concentration $\left(K_{e}\right)$ and membrane potential $\left(E_{m}\right)$ during repetitive synaptic stimulation. In this experiment, a conventional microelectrode was positioned intracellularly in a lumbar motoneuron and a $\mathrm{K}^{+}$-ion-sensitive microelectrode extracellularly in the motoneuron pool of the same segment. The lowest trace illustrates the recording of the reference barrel of the $\mathrm{K}^{+}$-ion-sensitive microelectrode (ref). The inset shows an action potential induced by antidromic stimulation of a ventral root followed by a postsynaptic potential induced by the first shock of the stimulus train.

of $\left[\mathrm{Na}^{+}\right]_{\mathrm{i}^{*}}$ The measurements presented in this paper were taken at least $30 \mathrm{~min}$ after impalement of the motoneuron, a time at which intracellular levels had reached a steady state.

\section{Free intracellular $\mathrm{K}^{+}$concentration $\left(\left[\mathrm{K}^{+}\right]_{i}\right)$}

In the steady state, the $\left[\mathrm{K}^{+}\right]_{\mathrm{i}}$ baseline varied between 80 and $105 \mathrm{mmol} / \mathrm{l}$ in motoneurons with resting membrane potentials of -70 to $-80 \mathrm{mV}$ and action potentials of $90-105 \mathrm{mV}$ amplitude (observations from 10 motoneurons). In motoneurons with lower resting membrane potentials of around $60 \mathrm{mV}$, $\left[\mathrm{K}^{+}\right]_{\mathrm{i}}$ was between 50 and $65 \mathrm{mmol} / \mathrm{l}$. During repetitive stimulation of a dorsal root $(10-20 \mathrm{~s}, 10-30 \mathrm{~Hz})$ a slow onset decrease of $\left[\mathrm{K}^{+}\right]_{i}$ was observable (Figs 1 and 8 ). The maximal change of $\left[\mathrm{K}^{+}\right]_{\mathrm{i}}$ measurable after such trains of stimuli was $5 \mathrm{mmol} / \mathrm{l}$. After the stimulation, it always took several minutes until $\left[\mathrm{K}^{+}\right]_{\mathrm{i}}$ returned to the baseline. It is noteworthy, that due to the Nernstian relation between voltage and concentration, relatively small voltage changes of the $\mathrm{K}_{i}^{+}$-signal were observed (see calibration of the upper trace in Fig. 1). For example, a $\mathrm{K}^{+}$-ion-sensitive microelectrode with a slope of $55 \mathrm{mV} /$ tenfold change of $\mathrm{K}^{+}$concentration monitors the decrease from $100 \mathrm{mmol} / 1$ to $96 \mathrm{mmol} / 1 \mathrm{~K}^{+}$as a voltage signal of $1 \mathrm{mV}$.

A comparison of the alteration in $\left[\mathrm{K}^{+}\right]_{\mathrm{i}}$ and the membrane potential $\left(\mathrm{E}_{\mathrm{m}}\right)$ of the motoneurons revealed one important deviation. After the end of the stimulation, $E_{m}$ always returned immediately to the resting potential followed by a post-tetanic membrane hyperpolarization (PTH). At this time, however, $\left[\mathrm{K}^{+}\right]_{\mathrm{i}}$ had just reached its lowest value before returning back to the baseline level (Figs 1 and 8).

Figure 2 illustrates the time course of the extracellular potassium concentration $\left[\mathrm{K}^{+}\right]_{\mathrm{e}}$ and the membrane potential of a frog spinal motoneuron during and after repetitive synaptic stimulation. It can be seen that $\left[\mathrm{K}^{+}\right]_{\mathrm{e}}$ reached its maximal level at the end of the repetitive stimulation and was still elevated at the time of the PTH. A comparison between the time course of $\left[\mathrm{K}^{+}\right]_{\mathrm{i}}$ and $\left[\mathrm{K}^{+}\right]_{\mathrm{e}}$ reveals that $\left[\mathrm{K}^{+}\right]_{\mathrm{e}}$ showed its maximal value before $\left[\mathrm{K}^{+}\right]_{\mathrm{i}}$ approached its lowest level. Additionally, the recovery time to the baseline was always shorter for $\left[\mathrm{K}^{+}\right]_{\mathrm{e}}$ than for $\left[\mathrm{K}^{+}\right]_{\text {. }}$. Summarizing the observations concerning the changes of $\left[\mathrm{K}^{+}\right]_{\mathrm{i}},\left[\mathrm{K}^{+}\right]_{\mathrm{e}}$ and the membrane potential in the post-stimulation period, it was observed that the membrane potential did not passively follow the transmembrane $\mathrm{K}^{+}$ion distribution.

\section{Free intracellular $\mathrm{Na}^{+}$concentration $\left(\left[\mathrm{Na}^{+}\right]_{i}\right)$}

After reaching a steady-state level, $\left[\mathrm{Na}^{+}\right]_{i}$ baseline varied between 4 and $16 \mathrm{mmol} / 1$ in motoneurons with resting membrane potentials of -75 to $-65 \mathrm{mV}$ (observations from 8 motoneurons). During repetitive stimulation of a dorsal root $(10-20 \mathrm{~s} ; 10-30 \mathrm{~Hz})$ an increase of $\left[\mathrm{Na}^{+}\right]_{i}$ with a slow onset was observed (Figs 3, 4, 5). The maximal increase of $\left[\mathrm{Na}^{+}\right]_{\mathrm{i}}$ measured after trains of stimuli with parameters described above was $5 \mathrm{mmol} / \mathrm{l}$. The time course of the $\left[\mathrm{Na}^{+}\right]_{\mathrm{i}}$ recovery resembled the observations made with the $\mathrm{K}^{+}$-ion-sensitive microelectrodes, in that several minutes elapsed until the baseline was reached. In Figs 3 and 4, the 2 types of ion exchanger resins used to measure $\left[\mathrm{Na}^{+}\right]_{\mathrm{i}}$ are compared. It is clear that the selectivity factor $\mathrm{Na}: \mathrm{K}$ determines the voltage change of the $\left[\mathrm{Na}^{+}\right]_{i}$ signal. The $\mathrm{Li}$-ion exchanger $\operatorname{resin}^{9}(\mathrm{Na}: \mathrm{K}=1: 0.2)$ gave $2 \mathrm{mV}$ voltage change for a $\left[\mathrm{Na}^{+}\right]_{\mathrm{i}}$ increase from 5 to $7 \mathrm{mmol} / \mathrm{l}$; whereas the Na-ion exchanger resin (ETH 227;20.26 $\mathrm{Na}: \mathrm{K}=1: 0.025$ ) gave an ion signal of nearly $10 \mathrm{mV}$ during the increase of $\left[\mathrm{Na}^{+}\right]_{i}$ from 4 to $7 \mathrm{mmol} / 1$.

\section{Post-tetanic membrane hyperpolarization (PTH)}

A series of experiments were performed in order to analyze whether an electrogenic $\mathrm{Na}^{+} / \mathrm{K}^{+}$pump mode is the main reason for the post-tetanic membrane hyperpolarization (PTH). First, in three experiments an intracellular $\mathrm{Na}^{+}$- and an extracellular $\mathrm{K}^{+}$-ionsensitive microelectrode were placed simultaneously in the motoneuron pool. This enabled us to observe the time course of $\left[\mathrm{K}^{+}\right]_{\mathrm{e}}\left[\mathrm{Na}^{+}\right]_{\mathrm{i}}$ and $\mathrm{E}_{\mathrm{m}}$ induced by tetanic stimulation of a dorsal root (Fig. 5). The results showed that the $\mathrm{PTH}$ occurred at a period when both $\left[\mathrm{Na}^{+}\right]_{\mathrm{i}}$ and $\left[\mathrm{K}^{+}\right]_{\mathrm{e}}$ were still elevated. Secondly, the membrane resistance was measured 


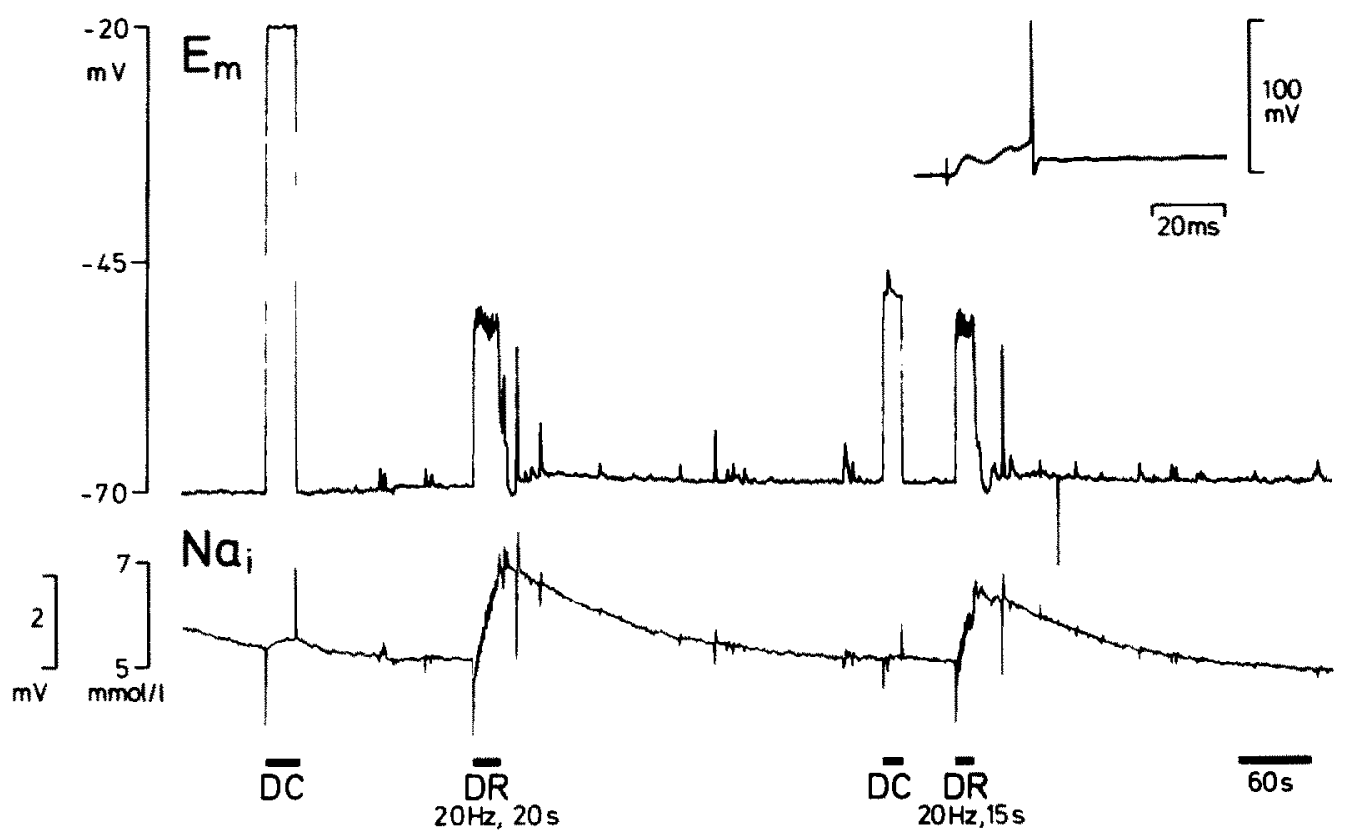

Fig. 3. Change of intracellular $\mathrm{Na}^{+}$concentration $\left(\mathrm{Na}_{i}\right)$ during repetitive stimulation of a lumbar dorsal root. In this experiment, the $\mathrm{Li}^{+}$-ion exchanger resin ${ }^{9}$ was used to determine $\mathrm{Na}_{\mathrm{i}}$. Due to the poor discrimination between $\mathrm{Na}$ and $\mathrm{K}$ (selectivity ratio 1:0.2) a voltage change of only $2 \mathrm{mV}$ was obtained during the increase of $\mathrm{Na}_{\mathrm{i}}$ from 5 to $7 \mathrm{mmol} / \mathrm{l}$ (cf Fig. 4). At the periods indicated by bars (DC), 50 and $20 \mathrm{mV}$ voltage steps were applied between the bath and the main ground. The inset shows a postsynaptic potential elicited by the first shock of the stimulus train.

$\mathrm{Na}_{i}$

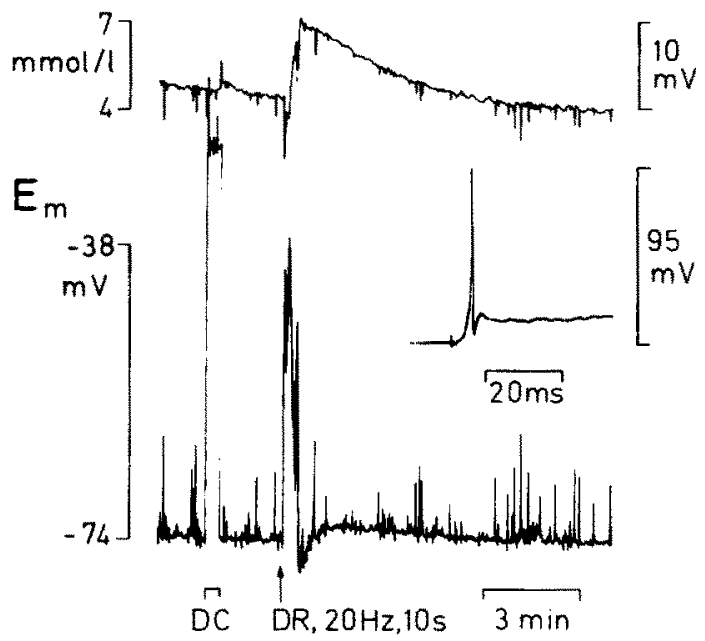

Fig. 4. Change of intracellular $\mathrm{Na}^{+}$concentration $\left(\mathrm{Na}_{\mathrm{i}}\right)$ during repetitive stimulation of a lumbar dorsal root. In this experiment, a $\mathrm{Na}^{+}$-ion exchanger $\mathrm{resin}{ }^{20,26}$ was used to determine $\mathrm{Na}_{\mathrm{i}}$. The good discrimination of $\mathrm{Na}$ against $\mathrm{K}$ (selectivity ratio 1:0.025) resulted in a voltage change of nearly $10 \mathrm{mV}$ during the increase of $\mathrm{Na}_{i}$ from 4 to $7 \mathrm{mmol} /$. At the time indicated by a bar (DC), a $50 \mathrm{mV}$ voltage step was applied between the bath and the main ground. The inset again shows the response elicited by the first shock of the stimulus train.
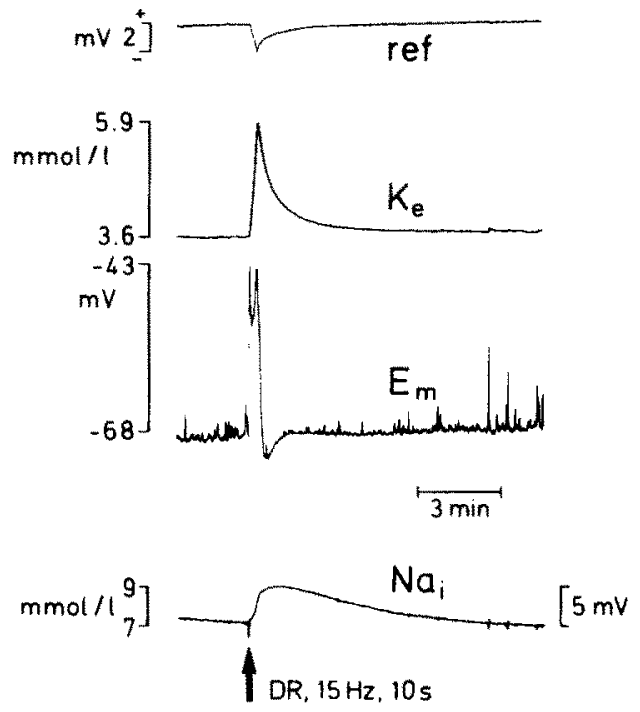

Fig. 5. Changes of extracellular $\mathbf{K}^{+}$concentration $\left(\mathrm{K}_{\mathrm{e}}\right)$, membrane potential $\left(\mathrm{E}_{\mathrm{m}}\right)$, and intracellular $\mathrm{Na}^{+}$concentration $\left(\mathrm{Na}_{i}\right)$ during repetitive stimulation of a dorsal root. In this experiment, a $\mathrm{Na}^{+}$-ion-sensitive microelectrode ${ }^{20.26}$ was placed intracellularly in a motoneuron and a $\mathrm{K}^{+}$-ion sensitive microelectrode extracellularly in the motoneuron pool of the same segment at a similar depth. The uppermost trace is the recording from the reference barrel of the extracellular $\mathrm{K}^{+}$-ion-sensitive microelectrode (ref). Note that the post-tetanic membrane hyperpolarization occurs at a time when $\mathrm{K}_{\mathrm{e}}$ and $\mathrm{Na}_{\mathrm{i}}$ are still elevated. 
A

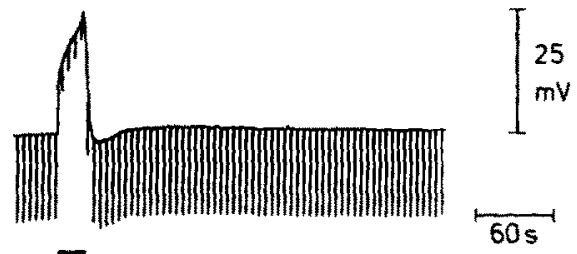

DR'̄ $2 \mathrm{~Hz}, 20 \mathrm{~s}$

B

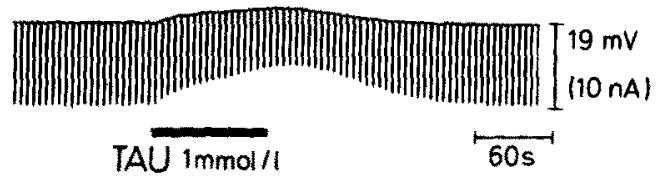

Fig. 6. Input resistance of a frog spinal motoneuron during the post-tetanic hyperpolarization. A: recording of the membrane potential during and after repetitive synaptic stimulation of a dorsal root. The hyperpolarizing deflections result from hyperpolarizing constant current pulses $(10 \mathrm{nA}, 100 \mathrm{~ms})$. Note that no change in the membrane resistance was observable during the post-tetanic membrane hyperpolarization. $B$ : The effect of taurine (TAU) on the input resistance of the same cell. Application of this amino acid into the bathing solution clearly reduced the input resistance. ${ }^{25}$ during the PTH using constant hyperpolarizing current pulses injected into the soma of the motoneurons (Fig. 6). Using this method, apparently no change of the input resistance was detectable in the 5 motoneurons tested (limitations in the interpretation will be discussed below). Thirdly, the action of ouabain on the PTH was investigated $(10$ cells $)$. Ouabain (3-10 $\mu \mathrm{mol} / 1)$ always completely blocked the PTH (Fig. 7). Finally, the effect of $\mathrm{Li}^{+}(15 \mathrm{mmol} / \mathrm{l}$; exchanged for $\mathrm{NaCl}$ ) on the PTH was also studied because of its suspected interaction with the electrogenic $\mathrm{Na}^{+} / \mathrm{K}^{+}$pump. ${ }^{21} \mathrm{Li}^{+}$reduced the amplitude of the PTH and also changed the amplitude and the time course of the $\left[\mathrm{K}^{+}\right]_{\mathrm{i}}$ signal as demonstrated in Fig. 8. Similar observations were made on a further 15 cells.

\section{DISCUSSION}

From the methodological point of view the interference of other ions or molecules with the ion exchanger resins used in this study has to be considered. There are no problems concerning the ionic interference of the $\mathrm{K}^{+}$ion exchanger used (Corning 477317; mean selectivity ratio $\mathrm{K}: \mathrm{Na}=70: 1$ ). However, it is well known that this ion exchanger is also

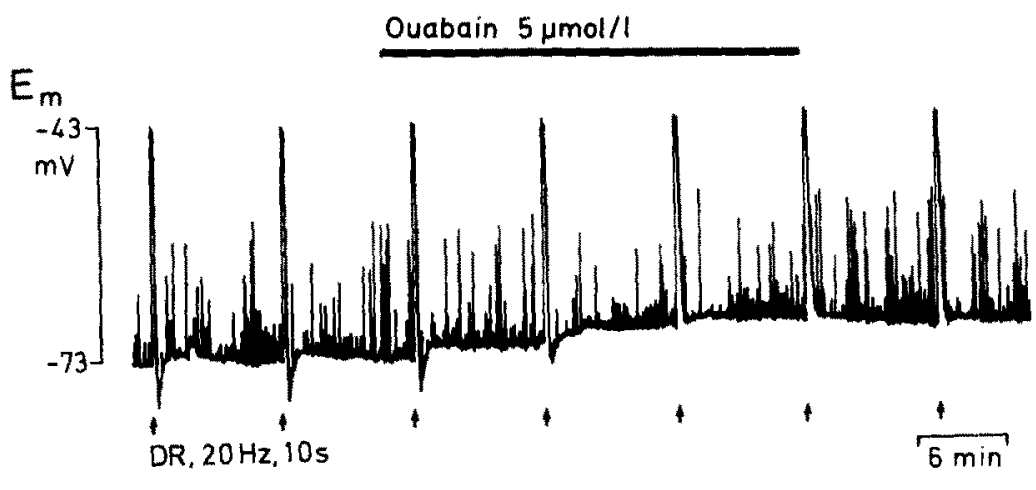

Control

Ouabain 10 umol/ $(+15 \mathrm{~min})$
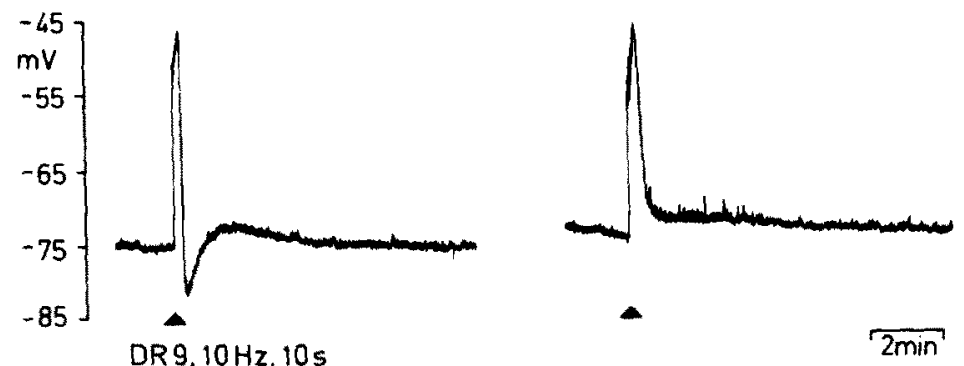

Fig. 7. Effect of ouabain on the post-tetanic membrane hyperpolarization. The upper trace shows a continuous intracellular recording of the membrane potential of a motoneuron. At the times indicated by the arrows, a dorsal root was stimulated repetitively $(20 \mathrm{~Hz}, 10 \mathrm{~s})$. Ouabain was added to the bathing solution during the period indicated by the bar. Note that ouabain completely blocked the PTH. In the lower traces, the PTH obtained in normal Ringer's solution (control) and its blockade after ouabain application are illustrated with a faster time base (another experiment) 


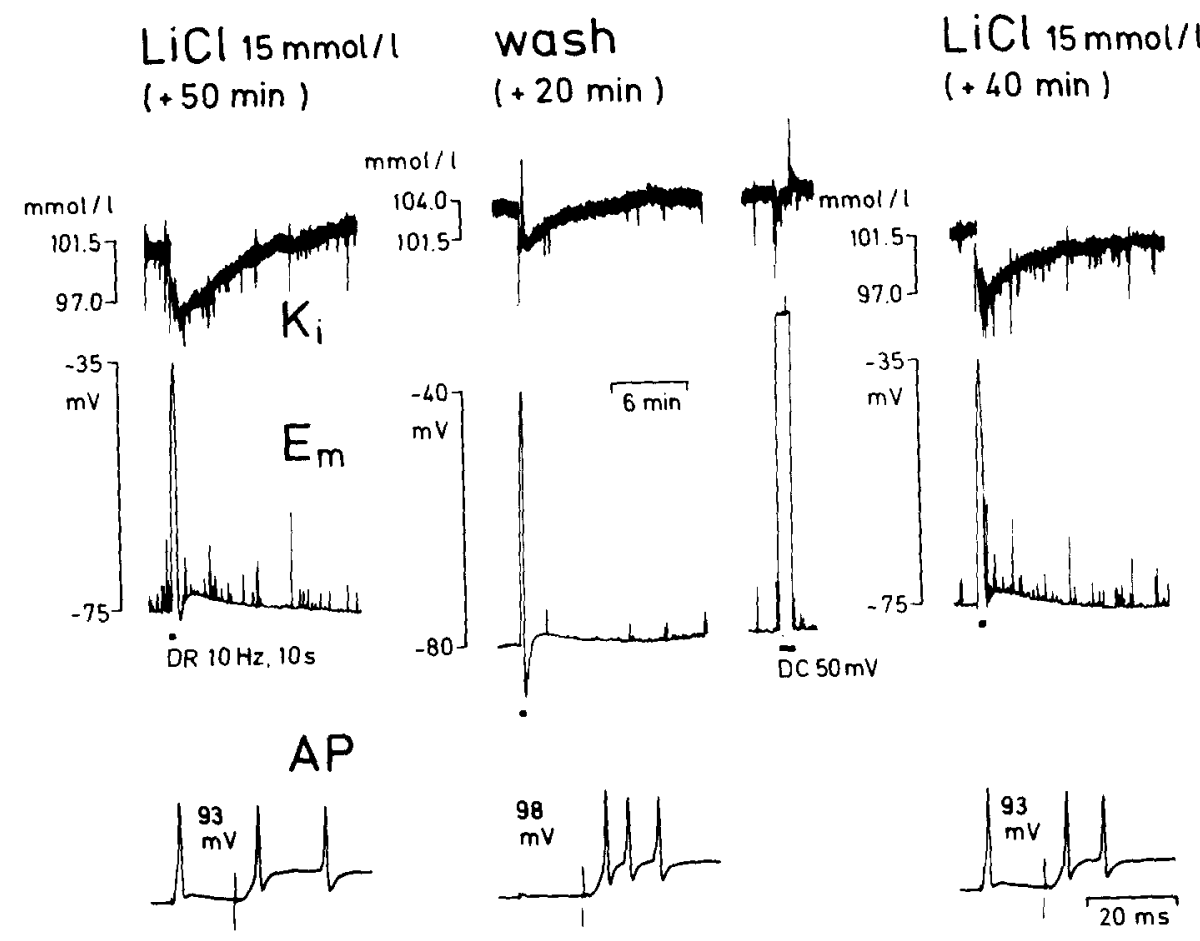

Fig. 8. Effect of $\mathrm{Li}^{+}$on the post-tetanic membrane hyperpolarization. The two upper traces to the left show the changes of the $\mathrm{K}_{\mathrm{i}}$ signal and the membrane potential of a motoneuron induced by repetitive stimulation of a dorsal root in the presence of $\mathrm{Li}^{+}$. The lowermost trace shows action potentials evoked by a single antidromic stimulus and the first dorsal root stimulus of the stimulus train. The 2 other columns demonstrate the same parameters after changing from a Ringer's solution containing $15 \mathrm{mmol} / \mathrm{l}$ $\mathrm{Li}^{+}$(exchanged for $\mathrm{NaCl}$ ) to normal Ringer's solution and back to the $\mathrm{Li}^{+}-\mathrm{R}$ inger. At the bar (DC), a $50 \mathrm{mV}$ voltage step was applied between the bath and the main ground. Note that $\mathrm{Li}^{+}$reduced the amplitude of the PTH and the AP-amplitude. In addition, $\mathrm{Li}^{+}$prolonged the time course and increased the amplitude of the $K_{i}$ signal simultaneously to a decrease of the $K_{i}$ baseline.

sensitive to quarternary ammonium ions. ${ }^{14}$ At present, we cannot completely exclude the possibility that an interference by some unknown cytoplasmic compound may contribute to the baseline or the kinetics of the observed ion signal. A valinomycin based $\mathrm{K}^{+}$-ion-sensitive microelectrode was not used due to the high resistance of the ion-sensitive barrel $(100 \mathrm{G} \Omega$; tip size $0.5 \mu \mathrm{m}$ ) which resulted in a very slow electrical time constant. Concerning the $\mathrm{Na}_{i}$ measurements, the high sensitivity of the ion exchanger (ETH $227^{20,26}$ ) for $\mathrm{Ca}^{2+}$-ions has to be considered. Calculations based on a selectivity ratio for $\mathrm{Ca}: \mathrm{Na}: \mathrm{K}=4: 1: 0.02$ reveal that the same voltage change of $4-5 \mathrm{mV}$ can be obtained by increasing $\left[\mathrm{Na}^{+}\right]_{i}$ from 8 to $10 \mathrm{mmol} / 1$ (background: $100 \mathrm{mmol} / 1 \mathrm{~K}^{+} ; 0.1 \mu \mathrm{mol} / 1 \mathrm{Ca}^{2+}$ ) or $\left[\mathrm{Ca}^{2+}\right.$ ] from 0.1 to $1 \mu \mathrm{mol} / 1$ (background: $100 \mathrm{mmol} / 1$ $\left.\mathrm{K}^{+} ; 10 \mathrm{mmol} / 1 \mathrm{Na}^{+}\right)$. However, two arguments suggest that the voltage change is indeed due to an increase of $\left[\mathrm{Na}^{+}\right]_{\mathrm{j}}$. First, control experiments in which we used intracellular $\mathrm{Ca}^{2+}$-ion-sensitive microelectrodes (ETH 1001) in frog spinal motoneurons did not show a voltage shift of more than $1-2 \mathrm{mV}$ during repetitive synaptic activation with our usual stimulation parameters (not illustrated). Experiments using $\mathrm{Ca}^{2+}$. ion-sensitive microelectrodes in snail neurons also revealed $\mathrm{Ca}_{j}$-signals in the range of only $1-2 \mathrm{mV}$ during a depolarization of $50 \mathrm{mV}$ amplitude from the resting membrane potential for a period of up to $20 \mathrm{~s}^{11}$ Therefore, it is rather unlikely that the voltage signal of up to $10 \mathrm{mV}$ obtained by the $\mathrm{Na}^{+}$ exchanger is entirely due to an increase in the intracellular $\mathrm{Ca}^{2+}$. Secondly, powerful mechanisms are known to exist that effectively bind $\mathrm{Ca}^{2+}$ entering the cytoplasm and therefore prevent a large increase of the free intracellular $\mathrm{Ca}^{2+}$ concentration. ${ }^{1}$ Therefore, we conclude that the $\mathrm{Ca}^{2+}$ interference with the $\mathrm{Na}^{+}$ion exchanger is of little significance for our measurements of the intracellular $\mathrm{Na}^{+}$-kinetics. However, it has to be taken into account for determining the $\mathrm{Na}^{+}$ baseline, since up to $30^{\circ}$ of the pure ion signal obtained by changing from the intra- to the extracellular space may be due to the $\mathrm{Ca}^{2+}$ concentration gradient.

Still another obstacle in evaluating the exact resting intracellular concentration is the unknown amplitude of the tip potential contributing to the voltage jump obtained from the reference barrel while withdrawing the electrode from the intra- to the extracellular 
space. In particular, the $\mathbf{K}_{i}$ baseline level may be under-or overestimated since a potential difference of $2 \mathrm{mV}$ of the pure ion signal may be reflected in a $\left[\mathrm{K}^{+}\right]$, baseline shift, for example, from 96 to $88 \mathrm{mmol} / \mathrm{l}$. This problem, however, should not contribute to the kinetics of the $\mathrm{K}_{\mathrm{i}}$ signal.

In the following part, both amplitude and time course of the $\left[\mathrm{K}^{+}\right]_{\mathrm{e}}$ and $\left[\mathrm{K}^{+}\right]_{\mathrm{i}}$ signals will be compared. A rough comparison between the amplitude of the $\left[\mathrm{K}^{+}\right]_{\mathrm{e}}$ rise and $\left[\mathrm{K}^{+}\right]_{\mathrm{i}}$ fall (Figs $\left.1,2,5,8\right)$ points to the importance of the glial uptake in determining the peak of the $\left[\mathrm{K}^{+}\right]_{\mathrm{e}}$ signal. Based on a volume ratio of $4: 1$ for the intra- to extracellular space one would expect $\mathrm{a}\left[\mathrm{K}^{+}\right]_{\mathrm{i}}$ fall in the concentration range of only one fourth of the $\left[\mathrm{K}^{+}\right]_{\mathrm{e}}$ rise. Our data, however, based on observations from different preparations using identical stimulation parameters $(20 \mathrm{~Hz}, 10 \mathrm{~s})$ show approximately an equimolar concentration change of $\left[\mathrm{K}^{+}\right]_{\mathrm{e}}$ and $\left[\mathrm{K}^{+}\right]_{\mathrm{i}}$. This indicates that remarkable amounts of $\mathrm{K}^{+}$must be taken up into glial cells. ${ }^{4,16}$ Diffusion alone, as the alternative factor regulating the $\left[\mathrm{K}^{+}\right]_{\mathrm{e}}$ amplitude, does not seem to be sufficient to account completely for the $\mathrm{K}^{+}$migration in the brain. ${ }^{5,18,30}$ Diffusion and active uptake into neurons and glial cells are also the factors determining the decay phase of the $\left[\mathrm{K}^{+}\right]_{e}$ signal. $^{4,5,10,12,15,16,18,30}$ In contrast to mammalian preparations, ${ }^{10}$ however, no $\mathrm{K}^{+}$undershoot was observable in the poststimulation period. This finding is in accordance with previous observations in the isolated spinal cord of the frog ${ }^{19,27}$ and might partly result from the temperature used in frog experiments $\left(20^{\circ} \mathrm{C}\right)$. Compared to the extracellular $\mathrm{K}^{+}$time course, a much slower shift of the $\left[\mathrm{K}^{+}\right]_{i}$-signal was observed. One important factor underlying this slow time course may be the diffusion from the center of the soma region (the most likely position of the electrode tip) to the membrane of the dendritic regions of the motoneurons.

Our data are consistent with the idea of an electrogenic $\mathrm{Na}^{+}$pump as the mechanism underlying the PTH. ${ }^{6,7,19}$ The hyperpolarization is not explainable by the post-tetanic change of the transmembrane $\mathrm{K}^{+}$ distribution, which should result in a membrane depolarization if no change of the membrane resistance occurs. However, we might have missed a change of the $\mathrm{K}^{+}$conductance in the dendrites of the motoneurons induced, for example, by a $\mathrm{Ca}^{2+}$-influx. In such a case, one would expect that the membrane hyperpolarization is electrotonically conducted to the soma region, whereas the permeability change may remain undetected. Furthermore, the complex synaptic input due to the repetitive stimulation of the dorsal roots makes it impossible to exclude completely a participation of an increased $\mathrm{K}^{+}$conductance in the production of PTH. On the other hand, the elevation of $\mathrm{Na}_{i}$ observed in our experiments is very likely a strong stimulus for the activation of the $\mathrm{Na}^{+} / \mathrm{K}^{+}$pump. In addition, ouabain, which is a well known inhibitor of the $\mathrm{Na}^{+} / \mathrm{K}^{+}$pump, completely blocked the PTH. $\mathrm{Li}^{+}$induced a similar effect, which may result from the competition of $\mathrm{Li}^{+}$and $\mathrm{K}^{+}$for a common binding site at the extracellular membrane surface. ${ }^{22}$ Additionally, $\mathrm{Li}^{+}$entering the cell through voltage-dependent $\mathrm{Na}^{+}$channels opened during the stimulation period, probably does not stimulate the intracellular $\mathrm{Na}^{+}$binding site. ${ }^{29}$ This should result in a lack of stimulation of the $\mathrm{Na}^{+} / \mathrm{K}^{+}$pump. These findings, therefore, also favour the idea of an electrogenic $\mathrm{Na}^{+} / \mathrm{K}^{+}$pump as the causative factor underlying the PTH. Finally, it is interesting to consider what cellular ionic environment would support a net depletion of positive charges from the cell. One answer might be that during synaptic activation an equivalent amount of $\mathrm{Na}^{+}$and $\mathrm{K}^{+}$are entering and leaving the motoneurons. A significant part of the extracellular $\mathrm{K}^{+}$, however, is taken up by the glial cells, ${ }^{4,16}$ consequently resulting in an imbalance of extracellular $\left[\mathrm{K}^{+}\right]$compared to intracellular $\left[\mathrm{Na}^{+}\right]$. In this situation, an electrogenic $\mathrm{Na}^{+}$pump with a coupling ratio of $3 \mathrm{Na}: 2 \mathrm{~K}$ is a suitable mechanism to remove the excess intracellular $\left[\mathrm{Na}^{+}\right]^{12}$

Acknowledgements-We are grateful to Prof. Simon, ETH Zürich, for the gift of the $\mathrm{Na}^{+}, \mathrm{Ca}^{2+}$ and $\mathrm{Li}^{+}$-exchanger and to him and Dr Ammann, ETH Zürich, for most valuable discussions throughout this project. We should like to thank Miss C. Koestler for participation in several experiments and Mrs C. Müller for expert technical and secretarial assistance. The work was supported by a grant given by the Deutsche Forschungsgemeinschaft ( $\mathrm{Br} 17-2)$.

\section{REFERENCES}

1. Baker P. F. \& Schlaepfer W. W. (1978) Uptake and binding of calcium by axoplasm isolated from giant axons of Loligo and Myxicola. J. Physiol., Lond. 276, 103-125.

2. Baylor D. A. \& Nicholls J. B. (1969) After-effects of nerve impulses on signalling in the central nervous system of the leech. J. Physiol., Lond. 203, 571-589.

3. Bührle C. P. \& Sonnhof U. (1981) Intracellular activities of $\mathrm{K}^{+}, \mathrm{Na}^{+}, \mathrm{Ca}^{2+}$ and $\mathrm{Cl}^{-}$in motoneurons and glia cells of the frog spinal cord. Pflügers Arch. ges. Physiol. 389, R24.

4. Coles J. A. \& Tsacopoulos M. (1979) Potassium activity in photoreceptors, glial cells and extracellular space in the drone retina: changes during photostimulation. J. Physiol., Lond. 290, 525-549.

5. Cordingley G. E. \& Somjen G. G. (1978) The clearing of excess potassium from extracellular space in spinal cord and cerebral cortex. Brain Res. 151, 291-306.

6. Czeh G., Kriz N. \& Sykova E. (1981) Extracellular potassium accumulation in the frog spinal cord induced by stimulation of the skin and ventrolateral columns. J. Physiol., Lond. 320, 57-72. 
7. Davidoff R. A. \& Hackman J. C. (1980) Hyperpolarization of frog primary afferent fibres caused by activation of a sodium pump. J. Physiol., Lond. 302, 297-309.

8. Grafe P.. Rimpel J., Reddy M. M. \& ten Bruggencate G. (1982) Lithium distribution across the membrane of motoneurons in the isolated frog spinal cord. Pfiugers Arch. ges. Physiol. 393, 297-301.

9. Güggi M., Fiedler U., Pretsch E. \& Simon W. (1975) A lithium ion-selective electrode based on a neutral carrier. Analyt. Lett. 8, 857-866.

10. Heinemann U. \& Lux H. D. (1975) Undershoots following stimulus-induced rises of extracellular potassium concentration in cerebral cortex of cat. Brain Res. 93, 63-76.

11. Hofmeier G. \& Lux H. D. (1981) The time courses of intracellular free calcium and related electrical effects after injection of $\mathrm{CaCl}_{2}$ into neurons of the snail, Helix pomatia. Pfiugers Arch. ges. Physiol. 391, 242-251.

12. Krnjevic K. \& Morris M. E. (1975) Factors determining the decay of $\mathrm{K}^{+}$potentials and focal potentials in the central nervous system. Can. J. Physiol. Pharmac. 53, 923-934.

13. Kuno M., Miyahara J. T. \& Weakly J. N. (1970) Post-tetanic hyperpolarization produced by an electrogenic pump in dorsal spinocerebellar tract neurons of the cat. J. Physiol., Lond. 210, 839-855.

14. Kuramoto T. \& Haber B. (1981) The $\mathrm{K}^{+}$liquid ion exchanger electrode system: responses to drugs and neurotransmitters. J. Neurosci. Res. 6, 37-48.

15. Lux H. D. \& Neher E. (1973) The equilibration time course of $\left(\mathrm{K}^{\dagger}\right)_{0}$ in cat cortex. Expl Brain Re*. 17, 190-205.

16. Mori S., Miller W. H. \& Tomita T. (1976) Müller cell function during spreading depression in frog retina. Proc. Nath Acad. Sci. U.S.A. 73, 1351-1354.

17. Nakajima S. \& Takahashi K. (1966) Post-tetanic hyperpolarization and electrogenic Na-pump in stretch receptor neurone of crayfish. J. Physiol., Lond. 187, 105-127.

18. Nicholson C., Phillips J. M. \& Gardner-Medwin A. R. (1979) Diffusion from an iontophoretic point source in the brain: role of tortuosity and volume fraction. Brain Res. 169, 580-584.

19. Nicoll R. A. (1979) Dorsal root potentials and changes in extracellular potassium in the spinal cord of the frog. $J$. Physiol. Land. 290, 113-127.

20. O'Doherty J., Garcia-Diaz J. F. \& McD. Armstrong W. (1979) Sodium-selective liquid ion-exchanger microelectrodes for intracellular measurements. Science, N.Y. 203, 1349-1351.

21. Ritchie J. M. \& Straub R. W. (1957) The hyperpolarization which follows activity in mammalian non-medullated fibres. I. Physiol., Lond. 136, $80-97$.

22. Smith I. C. H. (1979) The electrogenic potential in rat C nerve fibres: some effects of lithium and thallium. $J$. Physiol., Lond. 294, $135-144$.

23. Sonnhof U.\& Bührle Ch. (1981) An analysis of glutamate-induced ion fluxes across the membrane of spinal motoneurons of the frog. In Ghitamate as a Neurotransmitter (eds Dichiara G. \& Gessa G. L.) pp. 195-204. Raven Press. New York.

24. Sonnhof U., Förderer R., Schneider W. \& Kettenmann H. (1982) Cell puncturing with a step motor driven manipulator with simultaneous measurement of displacement. Pflügers Arch. ges. Physiol. 392, 295300.

25. Sonnhof U., Grafe P., Krumnikl J., Linder M. \& Schindler L. (1975) Inhibitory postsynaptic actions of taurine, GABA and other amino acids on motoneurons of the isolated frog spinal cord. Brain Res. 100, 327--341.

26. Steiner R. A., Oehme M., Ammann D. \& Simon W. (1979) Neutral carrier sodium ion-selective microelectrode for intracellular studies. Analyt. Chem. 51, 351--353.

27. Sykova E., Shirayev B.. Kriz N. \& Vyklicky L. (1976) Accumulation of extracellular potassium in the spinal cord of frog. Brain Res. 106, 413-417.

28. Tang C. M., Cohen M. W. \& Orkand R. K. (1980) Electrogenic pumps in axons and neuroglia and extracellular potassium homeostasis. Brain Res. 194, 283-286.

29. Thomas R. C. (1969) Membrane current and intracellular sodium changes in a snail neurone during extrusion of injected sodium. J. Physiol., Lond. 201, 495-514.

30. Vern B. A., Schuette W. H. \& Thibault L. E. (1977) $\left(\mathrm{K}^{+}\right)_{0}$ clearance in cortex: a new analytical model. J. Neurophysiol. 40, $1015-1023$ 